\title{
Assessing streamflow sensitivity to variations in glacier mass balance
}

\author{
Shad O’Neel • Eran Hood • Anthony Arendt • Louis Sass
}

Received: 10 July 2013 / Accepted: 19 December 2013 /Published online: 30 January 2014

C) The Author(s) 2014. This article is published with open access at Springerlink.com

\begin{abstract}
We examine long-term streamflow and mass balance data from two Alaskan glaciers located in climatically distinct basins: Gulkana Glacier, a continental glacier located in the Alaska Range, and Wolverine Glacier, a maritime glacier located in the Kenai Mountains. Over the 1966-2011 study interval, both glaciers lost mass, primarily as a result of summer warming, and streamflow increased in both basins. We estimate total glacier runoff via summer mass balance and quantify the fraction of runoff related to annual mass imbalances. In both climates, annual (net) mass balance contributes, on average, less than $20 \%$ of total streamflow, substantially less than the fraction related to summer mass loss $(>50 \%)$, which occurs even in years of glacier growth. The streamflow fraction related to changes in annual balance increased significantly only in the continental environment. In the maritime climate, where deep winter snowpacks and frequent rain events drive consistently high runoff, the magnitude of this streamflow fraction was small and highly variable, precluding detection of any existing trend. Furthermore, our findings suggest that glacier mass change is likely to impact total basin water yield, timing of runoff and water quality in the continental environment. However, the impacts of maritime glacier change appear more likely to be limited to water quality and runoff timing.
\end{abstract}

\section{Introduction}

The mountains ringing the Gulf of Alaska (GOA) receive upwards of 4-8 m yr ${ }^{-1}$ of precipitation (Simpson et al. 2005; Weingartner et al. 2005; O’Neel 2012), much of which runs off into productive coastal waters. The alpine landscape is heavily glacierized, and storage and turnover of water by glaciers substantially influences the regional surface water balance

Electronic supplementary material The online version of this article (doi:10.1007/s10584-013-1042-7) contains supplementary material, which is available to authorized users.

S. O’Neel $(\bowtie) \cdot$ L. Sass

US Geological Survey Alaska Science Center, 4210 University Dr, Anchorage, AK 99508, USA

e-mail: shad.oneel@gmail.com

E. Hood

Environmental Science Program, University of Alaska Southeast, Juneau, AK, USA

A. Arendt

Geophysical Institute, University of Alaska Fairbanks, Fairbanks, AK, USA 
(Neal et al. 2010). In turn, the land-to-ocean flux of freshwater impacts the biogeochemistry, physical oceanography, freshwater and marine ecology of the downstream components of the GOA ecosystem (e.g., Royer et al. 2001; Hood and Scott 2008). In this way, the links between terrestrial and ocean ecosystems along the GOA have widespread impacts on regional socioeconomic issues including water and hydropower resources, fish populations, and sea level change (Dorava and Milner 2000; Royer and Grosch 2006; Cherry et al. 2010; Gardner et al. 2013). Moreover, predicting future changes in physical, chemical and biological processes in near-shore ecosystems along the GOA hinges, in part, on developing a robust understanding of water storage and transfer by glaciers through streams to the ocean.

Glacierized basins (i.e. presently ice covered as opposed to glaciated, or historically ice covered) are very efficient producers of runoff, yielding 2-10 times greater runoff than similarly sized, non-glacierized basins (Mayo 1984). The unique energy balance that characterizes these basins (Jansson et al. 2003; Hock 2005) results in substantial alterations to streamflow, even when fractional ice coverage is very small (Stahl and Moore 2006). Consistent and precise treatment of glacier runoff is key to accurate assessment of hydrologic, ecological and socioeconomic impacts, but previously used definitions for glacier runoff are variable. They include: 1) meltwater produced as negative annual mass balance (e.g., Fountain and Tangborn 1985); 2) storage changes in the monthly water budget, where solid precipitation is balanced by melt and evaporation (Huss 2011, concept \#2); 3) meltwater derived from melting ice only (irrespective of melting snow or mass balance) (Nolin et al. 2010; Huss 2011, concept \#1); 4) all meltwater derived from the glacier surface (Cogley et al. 2011, meltwater runoff); 5) total runoff from the glacier surface (meltwater runoff plus rain on the glacier) (Neal et al. 2010).

Total glacier runoff (Definitions 4 and 5 above) includes a contribution from annual mass balance, i.e. the sum of accumulation and ablation through a mass balance year (Definition 1), or what has historically been referred to as the "net" balance (Cogley et al. 2011). Indeed, annual balance has been shown to be an important driver of streamflow trends in glacierized basins, with periods of persistent negative annual balance resulting in statistically significant increases in streamflow (e.g., Pellicciotti et al. 2010). However, in maritime climates, anomalies in glacier runoff can be disconnected from annual balance because of the high variability in winter precipitation. For example, positive anomalies in winter accumulation can result in elevated levels of glacier runoff in times of positive annual mass balance (Thayyen and Gergan 2010).

Quantifying the impacts of changing glacier geometries (annual balance) on glacier runoff is essential for predicting future changes in streamflow in glacierized basins. However, determining the role that this component plays in total glacier runoff (Definition 5) requires consistent measurements of seasonal (or shorter period) mass balances, measurements of precipitation at multiple locations within a basin, and streamflow measurements in close proximity to a glacier's terminus. Practical and logistical challenges associated with assembling such data sets typically preclude such partitioning. As a result, most analyses of the relationship between annual mass balance and streamflow rely on some component of model output to compute glacier runoff (e.g. Huss et al. 2008; Kaser et al. 2010). Ultimately, developing an understanding of how total glacier runoff will change in the future is critical for predicting downstream ecological impacts associated with changes in riverine fluxes of water, sediment, and solutes (e.g., metals and nutrients) to near-shore coastal ecosystems.

The purpose of this paper is to evaluate relationships among seasonal and annual glacier mass balances, glacier runoff and streamflow in two glacierized basins in different climate settings. We use long-term glacier mass balance and streamflow datasets from the United States Geological Survey (USGS) Alaska Benchmark Glacier Program to compare and contrast glacier-streamflow interactions in a maritime climate (Wolverine Glacier) with those in a continental climate (Gulkana Glacier). Our overall goal is to improve our understanding of 
how glacier mass balance processes impact streamflow, ultimately improving our conceptual understanding of the future evolution of glacier runoff in continental and maritime climates.

\section{Methods}

\subsection{Site description}

The USGS began consistent measurements of glacier mass balance, streamflow and meteorology at Gulkana and Wolverine glaciers in 1966. Although located only $\sim 350 \mathrm{~km}$ apart, the two glaciers are located in distinctly different climates. A continental (dry, cold) climate regime characterizes the eastern Alaska Range's Gulkana Glacier, while Wolverine Glacier, located on the Kenai Peninsula, is characterized by a maritime (wet, warm) climate (Fig. 1). These glaciers were chosen for long-term observation programs because they were thought to be representative of regional glacier-climate interactions (Meier et al. 1971). The records have been widely interpreted under this assumption (e.g., Hodge et al. 1998; Josberger et al. 2007). The two glaciers are comparable in size as are their watersheds (defined as the area draining to the USGS stream gages located directly downstream of each glacier). Both watersheds are heavily glacierized in excess of $50 \%$ (Fig. S1, Table S1).

\subsection{Data collection}

Seasonal and annual glacier mass balance is determined through a combination of the glaciological, or direct, method and the geodetic method (van Beusekom et al. 2010). Point measurements are integrated over a time variable glacier area to obtain sub-annual, glacierwide mass balances, presented as water mass in gigatons (Gt), or as specific balances, per unit area, in meters water equivalent (w.e.). Cumulative time series are adjusted using geodetic mass balance estimates (e.g., Huss et al. 2009). Assembly and quality of the 46-year record used here (1966-2011) is described in detail in the section S1 of the supplemental material.

Both glaciers discharge into a single stream, allowing basin runoff to be measured at stream gauges that were installed within $1.3 \mathrm{~km}$ of the 1967 termini on Phelan Creek (Gulkana Glacier) and Wolverine Creek (Tangborn et al. 1977). Streamflow data were obtained from the USGS National Water Information System (Wahl et al. 1995). The Phelan Creek record has 34 years of discontinuous data with an 11-year gap from 1979 to 1989 (March and O'Neel 2011). Data gaps permeate the Wolverine Creek record, but 25 years of gauging coincide with glacier mass balance measurements. Our analysis considers cumulative discharge over only the summer runoff months (defined as May-September), which represents greater than $90 \%$ of the annual flow in both basins.

Weather stations, installed on the glacier margins, record daily to sub-hourly values of temperature, precipitation, wind direction and wind speed. The stations have relatively continuous records since 1967, and gaps have been filled using monthly-derived scaling coefficients from nearby, low-elevation stations (van Beusekom et al. 2010). Snowfall measurements in these windy environments are problematic, and limit direct analysis of precipitation.

\subsection{Data analysis}

Our goal is to evaluate how glacier runoff, including its annual mass balance component $\left(B_{a}\right)$, contributes to streamflow in two unique climate regimes. We place minimal emphasis on forcing mechanisms in our analysis. It is also important to note that, as defined, the annual mass balance component of glacier runoff represents the proportion of glacier runoff 


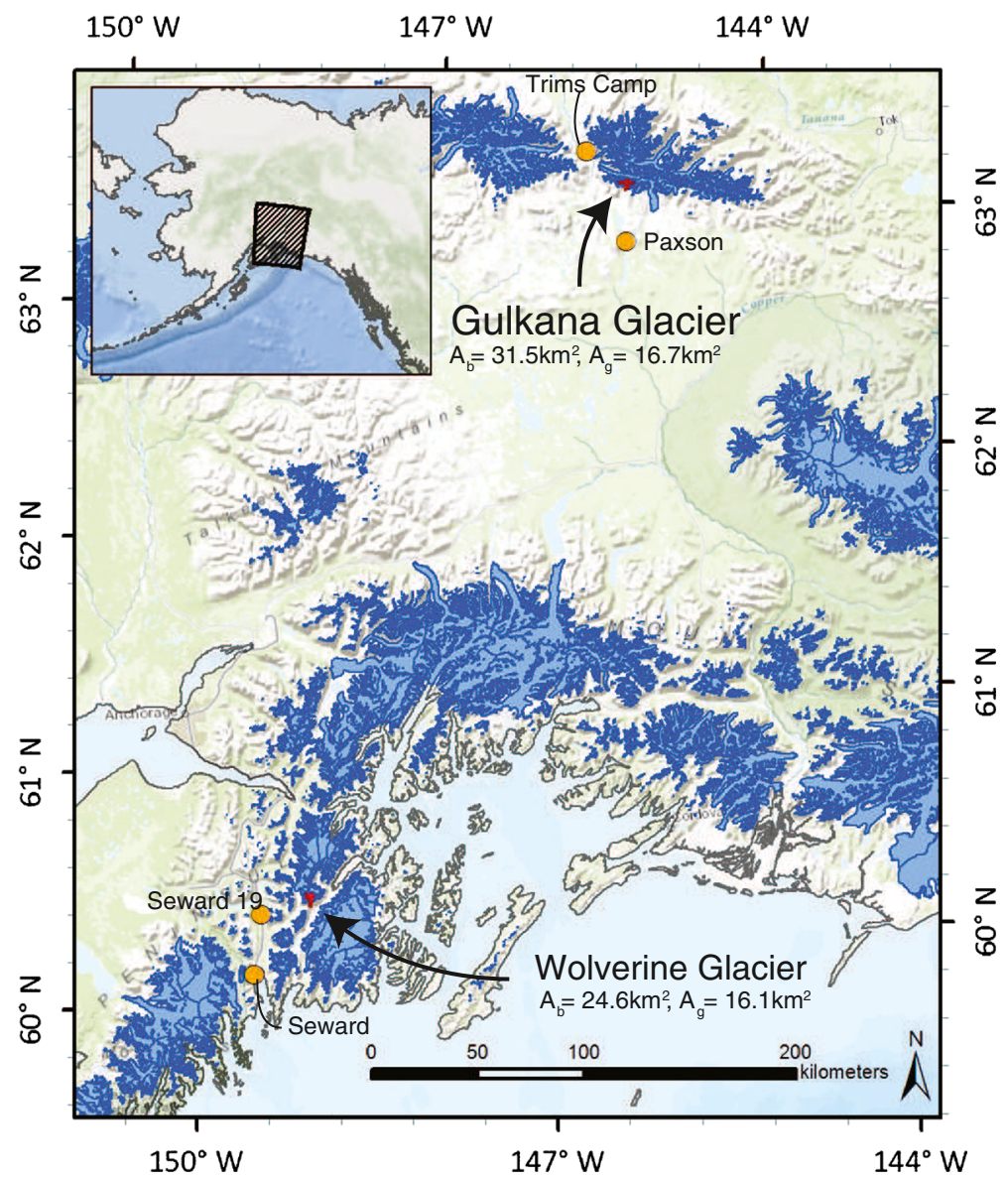

Fig. 1 Location of USGS Benchmark Glaciers. Gulkana Glacier is located in the Alaska Range (continental climate) and Wolverine Glacier is located in the Kenai Mountains (maritime climate). Basin areas $\left(A_{b}\right)$ and 2011 glacier areas $\left(A_{g}\right)$ are annotated. Orange symbols represent far-field weather stations used to fill datagaps

associated with a change in the glacier geometry (i.e., glacier volume change) over the balance year. We approximate glacier runoff $\left(Q_{g}\right)$ via the summer balance, $B_{s}$, which represents glacierwide mass loss between the spring mass maximum and fall mass minimum, and analyze patterns in glacier runoff through the fractional contributions of balance components (e.g., $B_{S}$ ) to summer streamflow, $Q_{s}$.

$$
Q_{g}=B_{s} / Q_{s}
$$

Our method is closest to Definition 2 of glacier runoff, in that we relate seasonal mass losses, that may or may not impact the total glacier volume, to glacier runoff. By relying entirely on mass balance observations targeted to the dates of maximum and minimum mass of the glacier system, we smooth over sub-seasonal discharge variations. This can be improved upon, for example, by using climate data to increase temporal resolution (e.g. Huss 2011), however in this paper we opt to focus entirely on direct observations. We lack data to quantify rain over the glacier area and water that may be stored in the glacier hydraulic system beyond the summer months that an ideal representation of glacier runoff would include. 
Relationships among mass balance terms $\left(B_{a}\right.$ and $\left.B_{s}\right)$ and streamflow are examined through correlation statistics and hypothesis testing (change and trend). At times, streamflow and mass balance data are presented in specific (area-weighted) units for comparability between the basins. We use volumetric units to minimize potential biases resulting from the variable basin size and fractional ice cover. Correlation coefficients, $r$, were evaluated in conjunction with probability values, $p$. Correlations were characterized as follows: 1) $r>0.6$ and $p<0.05$ was strong, 2) $0.3<r<0.6$ and $p<0.1$ was marginal; and $r<0.6$ and $p>0.10$ was non-significant. We tested for trends and change in the data using combined results of the Rank-sum and Mann-Kendall hypothesis tests, as described in supplemental material, section S2.

\section{Results}

3.1 Trends in climate, glacier mass balance, and streamflow

\subsubsection{Climate}

Mean annual temperature at each glacier's weather station was below freezing over the entire period of record. Weather stations at both glaciers recorded summer, winter and annual temperature increases over the study interval (Table S2). The largest change was summer temperature increase of $0.7^{\circ} \mathrm{C}$ at Wolverine Glacier. Annual changes were strongest at Gulkana (forced primarily by winter changes), and occurred at about half the rate observed at several low-elevation sites in Alaska (Wendler and Shulski 2009). Cumulative winter precipitation catch exceeded summer precipitation catch in both basins, but challenges in measuring winter precipitation prevent analyses for trends or change. A regional analysis of precipitation (1950-2002), based primarily on low-elevation weather stations, documents weak trends of increasing precipitation, with coastal stations showing both increases and decreases (Arendt et al. 2009). The best available metric for local changes in precipitation comes from winter balance, and no detectable trends or changes exist at either glacier (Table 1).

\subsubsection{Mass balance}

Larger and more variable seasonal and annual mass fluxes characterize the maritime environment (Fig. 2a, b). Both glaciers have experienced substantial mass loss over the study interval.

Table 1 Results from the Rank-sum change test over the intervals 1967-77 and 2001-2011 at Gulkana (G) and Wolverine (W) glaciers. Positive values indicate the parameter strengthened (i.e. negative annual balance became $66 \%$ more negative at Gulkana). Confidence levels are given in parentheses. Mann-Kendall trend results are in the far right column. Results were considered significant only when both tests were positive

\begin{tabular}{|c|c|c|c|}
\hline & \multicolumn{2}{|l|}{ Change } & \multirow[t]{2}{*}{ Trend } \\
\hline & Gulkana & Wolverine & \\
\hline$Q_{s}$ & $+14 \%(84)$ & $+23 \%(95)$ & W \\
\hline$B_{a}$ & $+66 \%(94)$ & $+20 \%(53)$ & G \\
\hline$B_{s}$ & $+28 \%(98)$ & $+17 \%(98)$ & G W \\
\hline$B_{w}$ & $+1 \%(20)$ & $+7 \%(66)$ & \\
\hline$B_{a} / Q_{s}$ & $+52 \%(91)$ & $+9 \%(26)$ & $\mathrm{G}$ \\
\hline$B_{s} / Q_{s}$ & $+11 \%(81)$ & $+2 \%(32)$ & \\
\hline
\end{tabular}



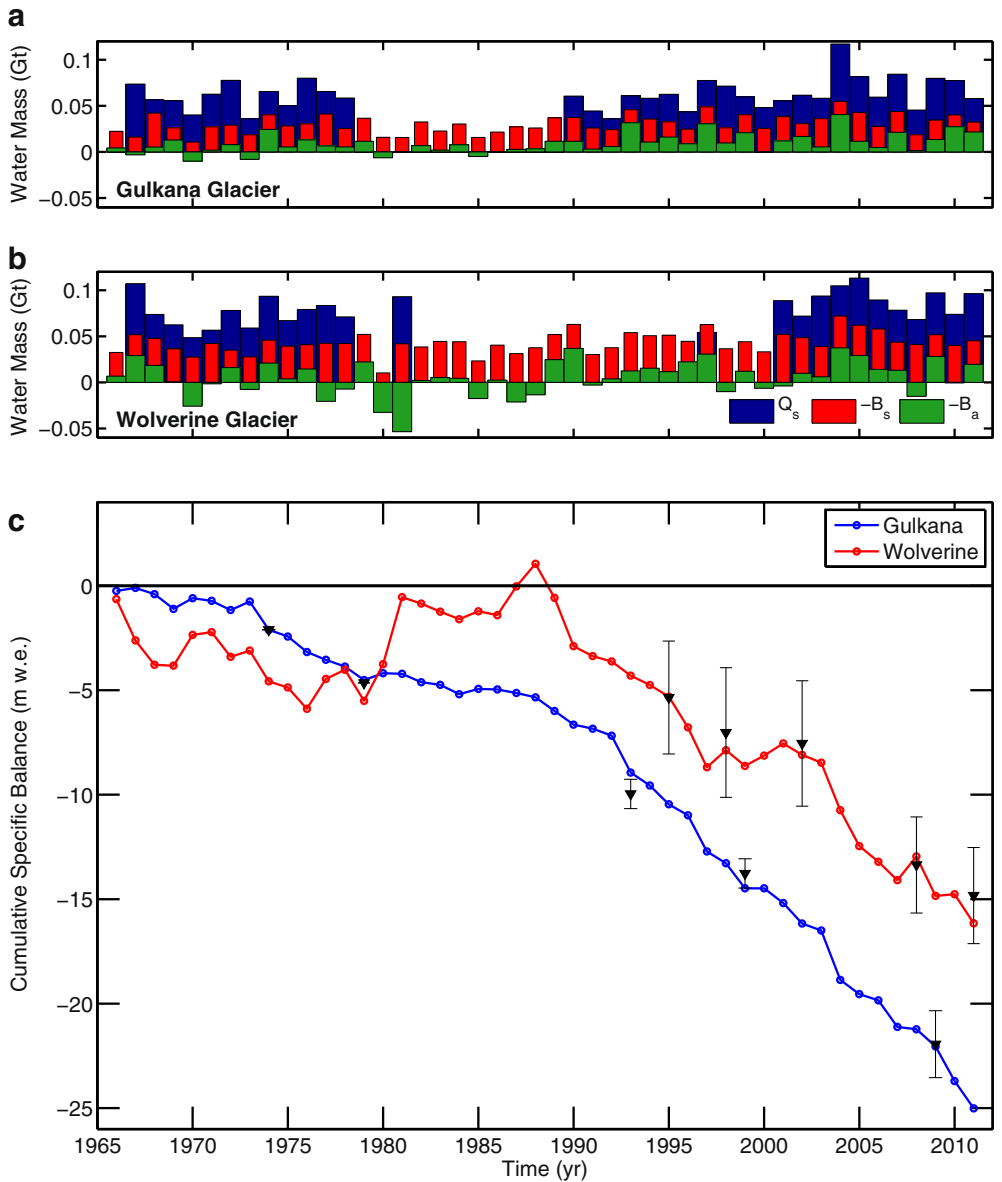

Fig. 2 Time series of summer discharge $\left(Q_{s}\right)$, summer mass balance $\left(B_{s}\right)$ and annual mass balance $\left(B_{a}\right)$ for Gulkana Glacier (a) and Wolverine Glacier (b). Summer and annual balances have been divided by negative one. Cumulative, glacier-wide specific mass balance (1966-2011) in units of meters water equivalent (w.e.) for Gulkana (blue) and Wolverine (red) glaciers from direct observations fitted to geodetic mass balance histories (c). Conventional annual balances are displayed with lines (i.e. time-variable glacier geometry). Geodetic observations derived from aerial photogrammetry are shown with black triangles. The geodetic series are referenced to direct observations in 1974 at Gulkana and 1978 at Wolverine

The cumulative balance series for Gulkana Glacier is nearly monotonically negative, reaching a minimum value of $-25.0 \mathrm{~m}$ in 2011 (Fig. 2c). The companion time series from Wolverine Glacier exhibits greater variability, but also reaches its $-16.2 \mathrm{~m}$ minimum in 2011. Episodes of positive glacier-wide mass balance (greater than uncertainty) have modulated mass loss at Wolverine Glacier several times since the observations began (Fig. 2b, c) with the most notable episode occurring in the late 1970s. At Gulkana Glacier, sustained negative mass balance has been associated with substantial area loss. Since 1966, approximately $17 \%$ of the basin was de-glacierized. The majority of mass loss at Wolverine Glacier has occurred via reduced glacier thickness. Fractional glacierization of the basin has decreased by only $4 \%$ since the program began, and most of the area loss has occurred in recent years (Table S1). 
Median annual balances for the period of record are nearly equal (Fig. 3a); the contrast in the cumulative balance series arises from the differences in variability and the direction of skewed outliers in the two populations. In accordance with negative cumulative mass balance history, the magnitude of the median summer balance exceeds the magnitude of the median winter balance at both glaciers (Fig. 3b, c). The magnitude of the summer balance is larger at Wolverine Glacier, in accordance with higher winter precipitation and summer melt rates in the lower and warmer coastal mountains. Variability, as measured by the interquartile range (IQR), of Gulkana Glacier summer balance is nearly double the variability of winter balance (Fig. 3b, c). This contrasts Wolverine Glacier where variability in the seasonal mass balance terms is roughly equal.

Correlations between seasonal and annual mass balances (Table S3) are related to the relative strength of summer and winter climate processes in annual mass balance (Hodge et al. 1998). At Gulkana Glacier, a strong correlation exists between annual and summer balance, but the correlation between annual and winter balances is marginal. This contrasts Wolverine Glacier, where both summer and winter balance are strongly correlated with annual balance. The rate of mass loss has increased at both glaciers since the late 1980s. Hypothesis test results, shown in Table 1, demonstrate that changes in summer balance are the primary mechanism for the shift in annual balance. We found no detectable changes in winter balance.
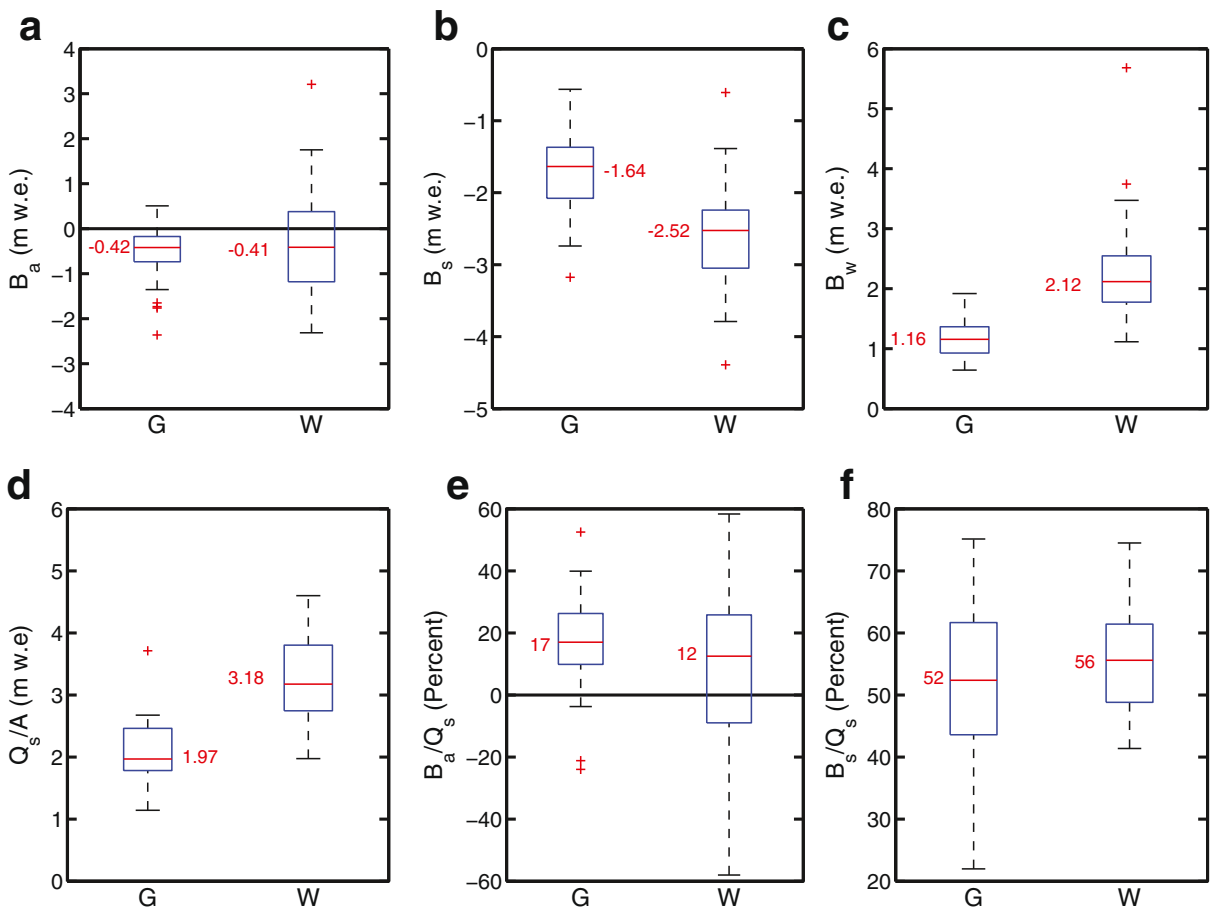

Fig. 3 Box plots for the period of record from Gulkana $(G)$ and Wolverine $(W)$ glaciers. a annual balance $\left(B_{a}\right)$, b summer balance, $\left(B_{s}\right)$, c winter balance $\left(B_{w}\right)$, d summer runoff $\left(Q_{s} / A\right)$, e fractional contribution of annual balance to discharge $\left(B_{a} / Q_{s}\right)$, f fractional contributions of summer balance to discharge $\left(B_{s} / Q_{s}\right)$. Boxes represent the interquartile range (IQR; 25th to 75th percentiles) of each population, with an annotated horizontal line marking the median value. Whiskers extend to the 5th and 95th percentiles, and outliers (when shown) are portrayed as crosses. In c, negative values indicate that the annual glacier mass balance was positive, such that annual streamflow was 'reduced' due to the increased storage by the glacier 


\subsubsection{Streamflow}

The hydrographs from Phelan and Wolverine creeks (Fig. 4) exhibit characteristics of streamflow in highly glacierized basins, including delayed maximum flow, and low year-to-year variability in spring and early summer (Fountain and Tangborn 1985; Fleming 2005). The rising limbs of the hydrographs are markedly similar, as a result of common timing of snowmelt onset. The maritime Wolverine Creek exhibits a broader peak as a result of the longer melt season and autumn rainstorms that impact the coast (Fig. 4). In general, summer streamflow volumes in Wolverine Creek exceed those in Phelan Creek (Fig. 3d), even though the Wolverine Creek basin is $22 \%$ smaller. Daily variability, as demonstrated in Fig. 4, is larger in the coastal climate, opposite of year-to-year variability, which is larger in the continental climate. The interannual variability of discharge in Phelan Creek spans four approximated standard deviations (Fig. S2), nearly a factor of two larger than Wolverine Creek. Regional coherence in summertime temperature across the region results in a moderate correlation $(r=0.53)$ for streamflow between the two basins (Table S2).

Hypothesis tests indicate that streamflow has increased in both watersheds, but with greater confidence in Wolverine Basin. Both trend (Mann-Kendall) and change (Rank-sum) tests show increases at Wolverine Creek over the study interval (Table 1). Although the Phelan Creek streamflow record is more complete, and Gulkana Glacier's mass balance more negative, trend tests failed, and the detected shift towards increased streamflow was only marginally significant. The high rates of interannual variability in Phelan Creek complicate trend detection, and these tests do not attribute changes to specific drivers.

\subsection{Relationships between glacier mass balance and streamflow}

To analyze the role of glacier mass balance in streamflow we evaluated correlations between the streamflow and balance time series (Table S3). The summer balance is strongly correlated

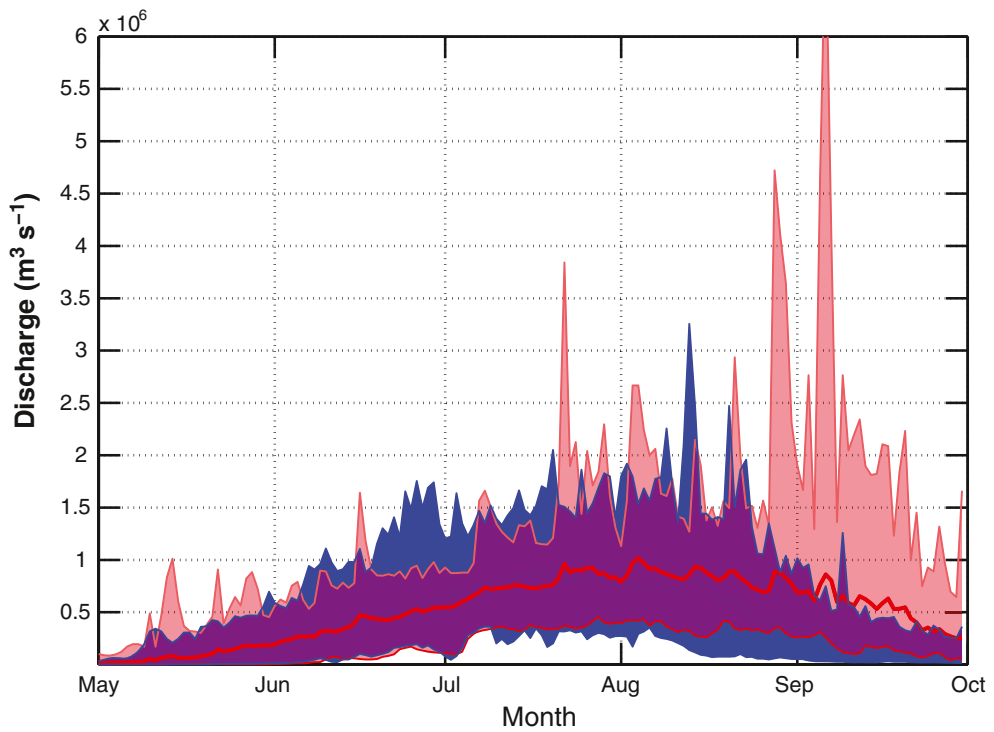

Fig. 4 Stacked summer hydrographs for Phelan (Blue) and Wolverine (red) creeks, where the solid line represents the daily mean discharge for all measurement years and the shaded regions represent the asymmetric daily range (e.g., max-mean and mean-min) for the same data 
to streamflow at both glaciers, and winter balance shows no correlation at either glacier. Annual balance correlates strongly with streamflow only at Gulkana Glacier. The correlation is only moderate for Wolverine Glacier. Statistical distributions (Fig. 3e) demonstrate the different character of the annual balance fraction of streamflow for the two glaciers. At Gulkana Glacier, this fraction ranges between 8 and $26 \%$, with a median value of $17 \%$. This component of streamflow exhibits a positive trend, and the rank-sum test suggests a doubling of the median value over the study interval. At Wolverine Glacier, the range was -9 to $23 \%$ with a median contribution of $15 \%$. Despite having similar median values, Wolverine has a $10 \%$ lower mean value (Fig. 3e). The central portion of this distribution includes negative values, indicating that years of positive annual balance are not exclusively outliers. No detectable changes or trends exist in this highly variable component of streamflow. The median summer balance fraction of streamflow is $52 \%$ at Gulkana Glacier and $55 \%$ at Wolverine Glacier. Although the median is slightly larger at Wolverine Glacier, Gulkana Glacier exhibits greater variability (Fig. 3f).

\section{Discussion}

Following previous convention, we assume that each glacier provides reasonable representation of its regional climate setting (e.g., Meier et al. 1971; Hodge et al. 1998). Our results support the paradigm that continental glaciers like Gulkana are predominantly influenced by summer temperature, while both summer temperature and winter precipitation significantly influence maritime glaciers like Wolverine (Arendt et al. 2009; Cuffey and Paterson 2010). Inter-glacier correlations between seasonal balances substantiate evidence that Alaskan summer temperatures are more coherent over larger spatial scales than is winter precipitation (e.g., Hodge et al. 1998; Arendt et al. 2013). Recent amplification of the summer balance at both glaciers provides the simplest explanation for the shift towards persistently negative annual balances since the early 1990s (Arendt et al. 2013). Maritime accumulation rates, nearly double those occurring in the continental climate regime, have historically buffered cumulative mass loss at Wolverine Glacier. However, as maritime glaciers are highly sensitive to climate forcing (De Woul and Hock 2005), continued lengthening of the melt season may promote a rapid decline in glacier mass. The low-elevation coastal glaciers of Alaska are increasingly susceptible to preferential shifts in the snow-rain fraction towards rain (Moore et al. 2009; Pellicciotti et al. 2010).

\subsection{Glaciological controls on streamflow}

Although streamflow sensitivity to small changes in glacier area is low when fractional basin ice cover exceeds 5-10 \% (Fountain and Tangborn 1985; Moore et al. 2009), observed streamflow changes may be related in part to basin characteristics (Table S1). Our results show that streamflow is increasing in both basins; however, the smaller Wolverine Basin has more ice cover, a slower rate of glacier area change, and produced more runoff. To ensure that differential rates of area change did not bias our results, we followed Fountain and Tangborn (1985) to estimate the runoff augmentation that would have occurred if Gulkana Glacier's area change was normalized to the lower Wolverine Glacier rate. The normalization results in a $2-3 \%$ change to runoff, suggesting that detected changes in streamflow are not solely related to variable rates of ice cover change.

The contribution of Gulkana's annual balance to streamflow has doubled over the study interval. This contrasts the variable and trendless annual balance contribution at Wolverine 
Creek. Average annual balance is similar in magnitude at both locations, but discharge from the glacier is augmented by negative annual balance more strongly in the continental climate, where variability in winter accumulation is low. The differences are exemplified by estimating the annual balance fraction of glacier runoff $\left(B_{a} / B_{s}\right)$. The median value of this fraction is $15 \%$ at Wolverine Glacier (mean is $3 \%$ ), and $26 \%$ at Gulkana (mean is $24 \%$ ). Accordingly, the ratio is increasing only at Gulkana.

At Gulkana Glacier, we found that discharge maxima in Phelan Creek occur when summer balance drives a strongly negative annual balance, thus highlighting the dependence of streamflow on summer temperature in continental climates. Our results illustrate that a simple relationship between streamflow and annual balance does not hold in the maritime climate. Here, high levels of streamflow may result from a low winter balance year followed by a warm summer in the same way as in the continental environment. However, positive streamflow anomalies may be associated with positive annual mass balance (glacier growth) during years of a positive winter balance anomaly and large associated snowmelt (both on the glacier and surrounding seasonal snowcover; (Thayyen and Gergan 2010)). Additionally, in the maritime climate late summer rainstorms consistently provide large contributions to streamflow (Fig. 4). Such complex streamflow drivers prevent strong correlations between changes in annual mass balance and summer streamflow, and preclude resolution of any existing trends. This finding agrees with Kaser et al. (2010) who found that even if annual negative balance doubled, impacts on discharge in large river systems would still be less than interannual variability.

\subsection{Changing physical system}

The long-term benchmark glacier datasets elucidate the future role of glaciers in the hydrologic cycle given predictions of continued warming and glacier recession (e.g., Radić et al. 2013). Although annual mass balance inherently modifies discharge, it is generally a small fraction of total glacier runoff. Seasonal mass losses, which occur independently of changes in annual balance, can exhibit an equally strong or stronger control on streamflow, especially in maritime climates (Hagen et al. 2003; Thayyen and Gergan 2010). As glaciers continue to recede, the timing of peak flows is likely to shift to be earlier and narrower, more closely resembling hydrographs from snowmelt-dominated basins (Déry et al. 2009), with lesser impacts to overall basin water yields. Changes will be more pronounced in continental climates where the annual balance fraction of streamflow is large and plays an essential role in sustaining late summer streamflow (Kaser et al. 2010). Ultimately, these changes in runoff timing will impact water availability, particularly in regions that do not have adequate reservoir storage capacity to redistribute the earlier runoff.

It is important to note that glaciers function to augment basin runoff by reducing the proportion of the annual snowpack that is lost to evapotranspiration (Huss et al. 2008). This effect is particularly important in maritime areas where vegetative succession occurs rapidly following de-glacierization, and results in the establishment of forests in which a large proportion of the annual snowfall can be lost to interception and transpiration (Frank and Inouye 1994).

\subsection{Changing biogeochemical and ecological systems}

Beyond the well-documented role of glacier runoff for water resources, sea level rise and hazards (Fountain and Tangborn 1985; Hagen et al. 2003; Gardner et al. 2013), glacier runoff also impacts the biogeochemistry and ecology of downstream freshwater and marine ecosystems (Fleming 2005; Hodson et al. 2008). Studies often focus on how glacier change will impact basin water yields, independent of any issues related to water quality (e.g., Kaser et al. 
2010). However, from a biogeochemical perspective, it is the proportion of basin runoff delivered from the glacier surface to the river (including rainfall on the glacier) that is important, because this fraction of streamflow contains the unique biogeochemical signature of glacier runoff. For example, glacier runoff has a pronounced impact on physical water properties including temperature and turbidity that exhibit control on the structure and abundance of riverine ecological communities (Jacobsen et al. 2012). Changes in the timing of streamflow associated with the loss of glaciers have the potential to impact endemic aquatic species that are adapted to glacier runoff (Muhlfeld et al. 2011). Additionally, runoff from glaciers can increase riverine fluxes of rock-derived elements such as $\mathrm{P}$ and Fe (Hodson et al. 2004; Schroth et al. 2011), and bioavailable dissolved organic matter (Hood et al. 2009; Singer et al. 2012) delivered to downstream food webs. Thus there may be pronounced changes in riverine biogeochemistry and ecology associated with the loss of glaciers even if total basin water yields do not change substantially.

Overall, our results clearly indicate that the annual balance term should not be considered to represent glacier runoff in any studies seeking to address biogeochemical and ecological impacts of runoff from glaciers. This term constitutes a relatively modest proportion of total glacier runoff, even when only estimated to first order via the summer balance. Inclusion of rainfall over the glacier area would strengthen all results presented herein. Especially in maritime climates, decreases in summer runoff associated with shrinking glaciers will be masked by the large interannual variability in perennial snow and summer rainfall events. The runoff related to annual balance, or glacier geometry changes, should be referred to as such; case-specific definitions and deviations from the Cogley et al. (2011) definition of glacier runoff should be clearly addressed in future studies aimed at understanding how glacier change is impacting hydrology, biogeochemistry, and ecology at the watershed to regional scale.

\section{Conclusions}

We analyzed mass balance and streamflow data from Gulkana and Wolverine glaciers to show that both are losing mass as a result of stronger summer ablation. We estimated total glacier runoff via summer mass balance, and separated the fraction related to annual balance (changes in glacier geometry). In both cases, the annual balance fraction of streamflow is significantly smaller than the fraction related to summer mass losses, which occur even in years of positive annual balance (glacier growth). The fractional contribution of annual balance to streamflow has increased strongly at Gulkana Glacier, but at Wolverine Glacier this streamflow fraction exhibits no trend. In the continental climate, positive streamflow anomalies arise primarily from negative annual mass balance anomalies. Our analysis agrees with previous assertions that maritime glaciers are more sensitive to climate than glaciers located in continental climates (e.g. De Woul and Hock 2005). In the more complex maritime climate, streamflow has multiple drivers, including melt, and highly variable rainfall and snow accumulation. Although it is common to assume that discharge varies proportionally to annual mass balance for heavily glacierized basins, our data shows in maritime climates discharge is less coupled to annual mass balance than the delivery of summer mass balance to outlet streams. Especially in maritime climates, we expect that anticipated future glacier mass losses will impact water quality more prominently than total basin water yield, and potentially shift the timing of melt onset earlier in the spring, underscoring the need for ecological studies to focus attention on the future evolution of total glacier runoff instead of the more commonly estimated annual balance runoff fraction.

Improved understanding of the downstream ecology that is closely coupled to the physical properties of glacier-fed streams along the GOA coast requires an improved understanding of 
total glacier runoff, not just the fraction related to changing glacier geometries. Future studies should be clear in their use of the term "glacier runoff" given that it has been used inconsistently in the past and has different implications for hydrology versus biogeochemistry and ecology.

Acknowledgments Funding from the U.S. Geological Survey Climate and Land Use Research and Development program, the U.S. Department of Interior Alaska Climate Science Center, the U.S. National Science Foundation (EAR-0943599) and NASA's Cryospheric Sciences program (NNX13AK37G) supported this research. J. Rich provided assistance with figure production. We thank Rod March, Larry Mayo and Dennis Trabant, along with countless others that have participated in constructing the benchmark glacier records that form the backbone of this study. Andrew Fountain, Matthias Huss and Jeremy Littell provided comments that improved the manuscript.

Open AccessThis article is distributed under the terms of the Creative Commons Attribution License which permits any use, distribution, and reproduction in any medium, provided the original author(s) and the source are credited.

\section{References}

Arendt A, Luthcke S, Gardner A et al (2013) Analysis of a GRACE global mascon solution for Gulf of Alaska glaciers. J Glaciol 59:913-924. doi:10.3189/2013JoG12J197

Arendt A, Walsh J, Harrison W (2009) Changes of glaciers and climate in northwestern North America during the late twentieth century. J Clim 22:4117-4134. doi:10.1175/2009JCLI2784.1

Cherry J, Walker S, Fresco N et al. (2010) Impacts of climate change and variability on hydropower in Southeast Alaska: Planning for a robust energy future.

Cogley JG, Hock R, Rasmussen LA et al (2011) Glossary of glacier mass balance and related terms: Paris. Int Assoc Cryospheric Sci IHP-VII Tech Doc Hydrol 86:124

Cuffey KM, Paterson WS (2010) The physics of glaciers, 4th edn. Elsevier, Oxford

De Woul M, Hock R (2005) Static mass-balance sensitivity of arctic glaciers and ice caps using a degree-day approach. Ann Glaciol 42:217-224. doi:10.3189/172756405781813096

Déry SJ, Stahl K, Moore RD et al (2009) Detection of runoff timing changes in pluvial, nival, and glacial rivers of western Canada. Water Resour Res. doi:10.1029/2008WR006975

Dorava JM, Milner AM (2000) Role of lake regulation on glacier-fed rivers in enhancing salmon productivity: The cook inlet watershed, south-central Alaska, USA. Hydrol Process 14:3149-3159. doi:10.1002/10991085(200011/12)14:16/17<3149::AID-HYP139>3.0.CO;2-Y

Fleming SW (2005) Comparative analysis of glacial and nival streamflow regimes with implications for lotic habitat quantity and fish species richness. River Res Appl 21:363-379. doi:10.1002/rra.810

Fountain AG, Tangborn WV (1985) The effect of glaciers on streamflow variations. Water Resour Res 21:579586. doi:10.1029/WR021i004p00579

Frank DA, Inouye RS (1994) Temporal variation in actual evapotranspiration of terrestrial ecosystems: Patterns and ecological implications. J Biogeogr 21:401-411. doi:10.2307/2845758

Gardner AS, Moholdt G, Cogley JG et al (2013) A reconciled estimate of glacier contributions to sea level rise: 2003 to 2009. Science 340:852-857. doi:10.1126/science. 1234532

Hagen JO, Kohler J, Melvold K, Winther J-G (2003) Glaciers in Svalbard: Mass balance, runoff and freshwater flux. Polar Res 22:145-159. doi:10.1111/j.1751-8369.2003.tb00104.x

Hock R (2005) Glacier melt: A review of processes and their modelling. Prog Phys Geogr 29:362-391. doi:10. 1191/0309133305pp453ra

Hodge SM, Trabant DC, Krimmel RM et al (1998) Climate variations and changes in mass of three glaciers in Western North America. J Clim 11:2161-2179. doi:10.1175/1520-0442(1998)011<2161:CVACIM>2.0.CO;2

Hodson A, Anesio AM, Tranter M et al (2008) Glacial ecosystems. Ecol Monogr 78:41-67. doi:10.1890/07-0187.1

Hodson A, Mumford P, Lister D (2004) Suspended sediment and phosphorus in proglacial rivers: Bioavailability and potential impacts upon the P status of ice-marginal receiving waters. Hydrol Process 18:2409-2422. doi: 10.1002/hyp.1471

Hood E, Fellman J, Spencer RGM et al (2009) Glaciers as a source of ancient and labile organic matter to the marine environment. Nature 462:1044-1047. doi:10.1038/nature08580

Hood E, Scott D (2008) Riverine organic matter and nutrients in southeast Alaska affected by glacial coverage. Nat Geosci 1:583-587. doi:10.1038/ngeo280 
Huss M (2011) Present and future contribution of glacier storage change to runoff from macroscale drainage basins in Europe. Water Resour Res. doi:10.1029/2010WR010299

Huss M, Bauder A, Funk M (2009) Homogenization of long-term mass-balance time series. Ann Glaciol 50: 198-206. doi:10.3189/172756409787769627

Huss M, Farinotti D, Bauder A, Funk M (2008) Modelling runoff from highly glacierized alpine drainage basins in a changing climate. Hydrol Process 22:3888-3902. doi:10.1002/hyp.7055

Jacobsen D, Milner AM, Brown LE, Dangles O (2012) Biodiversity under threat in glacier-fed river systems. Nat Clim Change 2:361-364. doi:10.1038/nclimate1435

Jansson P, Hock R, Schneider T (2003) The concept of glacier storage: A review. J Hydrol 282:116-129. doi:10. 1016/S0022-1694(03)00258-0

Josberger EG, Bidlake WR, March RS, Kennedy BW (2007) Glacier mass-balance fluctuations in the Pacific Northwest and Alaska, USA. Ann Glaciol 46:291-296. doi:10.3189/172756407782871314

Kaser G, Großhauser M, Marzeion B (2010) Contribution potential of glaciers to water availability in different climate regimes. Proc Natl Acad Sci 107:20223-20227. doi:10.1073/pnas.1008162107

March RS, O’Neel S (2011) Gulkana Glacier, Alaska-mass balance, meteorology, and water measurements, 1997-2001. US Geol Surv Sci Investig Rep Sci Investig Rep 2011:84

Mayo LR (1984) Glacier mass balance and runoff research in the USA. Geog Ann 66A:215-227

Meier MF, Tangborn W, Mayo LR, Post A (1971) Combined ice and water balances of Gulkana and Wolverine glaciers, Alaska, and South Cascade Glacier, Washington, 1965 and 1966 hydrologic years. US Geol Surv Prof Pap 715-A: 23

Moore RD, Fleming SW, Menounos B et al (2009) Glacier change in western North America: Influences on hydrology, geomorphic hazards and water quality. Hydrol Process 23:42-61. doi:10.1002/hyp.7162

Muhlfeld CC, Giersch JJ, Hauer FR et al (2011) Climate change links fate of glaciers and an endemic alpine invertebrate. Clim Change 106:337-345. doi:10.1007/s10584-011-0057-1

Neal EG, Hood E, Smikrud K (2010) Contribution of glacier runoff to freshwater discharge into the Gulf of Alaska. Geophys Res Lett. doi:10.1029/2010GL042385

Nolin AW, Phillippe J, Jefferson A, Lewis SL (2010) Present-day and future contributions of glacier runoff to summertime flows in a Pacific Northwest watershed: Implications for water resources. Water Resour Res. doi:10.1029/2009WR008968

O’Neel S (2012) Surface mass balance of Columbia Glacier, Alaska, 1978 and 2010 balance years. US Geol Surv Data Ser 676:8

Pellicciotti F, Bauder A, Parola M (2010) Effect of glaciers on streamflow trends in the Swiss Alps. Water Resour Res. doi:10.1029/2009WR009039

Radić V, Bliss A, Beedlow AC et al. (2013) Regional and global projections of twenty-first century glacier mass changes in response to climate scenarios from global climate models. Clim Dyn 1-22. doi: 10.1007/s00382-013-1719-7

Royer TC, Grosch CE (2006) Ocean warming and freshening in the northern Gulf of Alaska. Geophys Res Lett. doi:10.1029/2006GL026767

Royer TC, Grosch CE, Mysak LA (2001) Interdecadal variability of Northeast Pacific coastal freshwater and its implications on biological productivity. Prog Oceanogr 49:95-111. doi:10.1016/S0079-6611(01)00017-9

Schroth AW, Crusius J, Chever F et al. (2011) Glacial influence on the geochemistry of riverine iron fluxes to the Gulf of Alaska and effects of deglaciation. Geophys Res Lett 38. doi: 10.1029/2011GL048367.

Simpson JJ, Hufford GL, Daly C et al (2005) Comparing maps of mean monthly surface temperature and precipitation for Alaska and adjacent areas of Canada produced by two different methods. Arctic 58:137-161

Singer GA, Fasching C, Wilhelm L et al (2012) Biogeochemically diverse organic matter in Alpine glaciers and its downstream fate. Nat Geosci 5:710-714. doi:10.1038/ngeo1581

Stahl K, Moore RD (2006) Influence of watershed glacier coverage on summer streamflow in British Columbia, Canada. Water Resour Res. doi:10.1029/2006WR005022

Tangborn W, Mayo LR, Scully DR, Krimmel RM (1977) Combined ice and water balances of Maclure Glacier, California, South Cascade Glacier, Washington, and Wolverine and Gulkana Glaciers, Alaska-1967 hydrologic year. US Geol Surv Prof Pap 20

Thayyen RJ, Gergan JT (2010) Role of glaciers in watershed hydrology: A preliminary study of a "Himalayan catchment.". Cryosphere 4:115-128

Van Beusekom AE, O’Neel S, March RS et al (2010) Re-analysis of Alaskan benchmark glacier mass-balance data using the index method. US Geol Surv Sci Investig Rep 2010:16

Wahl KL, Thomas WO, Hirsch RM (1995) Stream-gauging program of the U.S. geological survey. US Geol Surv Circ 1123:22

Weingartner TJ, Danielson SL, Royer TC (2005) Freshwater variability and predictability in the Alaska coastal current. Deep Sea Res Part II Top Stud Oceanogr 52:169-191. doi:10.1016/j.dsr2.2004.09.030

Wendler G, Shulski M (2009) A century of climate change for Fairbanks, Alaska. ARCTIC 62:295-300 